\title{
KUALITAS PEMBELAJARAN AL-QUR'AN DENGAN METODE TARTILA DI TPQ SABILUN NAJAH SAMBIROTO TAMAN SIDOARJO
}

\author{
Khalimatus Sa'diah \\ (Alumni IAIN Sunan Ampel Fak. Tarbiyah Jurusan PAI)
}

\begin{abstract}
Abstrak
Penelitian ini mengandung persoalan: Bagaimanakah pelaksanaan pembelajaran al-Qur'an dengan menggunakan metode Tartila di TPQ Sabilun Najah Sambiroto, Taman-Sidoarj, dan bagaimanakah kualitas bacaan alQur'an Santri di TPQ Sabilun Najah Sambiroto, Taman-Sidoarjo.

Dalam rangka menjawab pertanyaan diatas, peneliti melakukan penelitian deskriptif kualitatif, sehingga hasil yang diperoleh berupa deskripsi-deskripsi data yang terurai. Pengumpulan data dilakukan dengan cara observasi, dokumentasi, dan interview.

Hasil penelitian menyimpulkan bahwa metode tartila sangat efektif dalam meningkatkan kualitas bacaan santri TPQ Sabilun Najah Sambiroto Taman Sidoarjo dengan indikator-indikator sebagai berikut: santri mampu membaca al-Qur'an dengan lancar, santri mampu membaca al-Qur'an dengan benar, santri berhati-hati dalam membaca al-Qur'an, santri mampu merasakan ketika ada bacaan yang tidak sesuai dengan kaidah tajwid.
\end{abstract}

Kata Kunci: Pembelajaran Al-Quran, Tartila dan Santri TPQ Sabilun Najah 


\section{A. Pendahuluan}

Pendidikan merupakan kewajiban bagi setiap warga yang merupakan cerminan akan maju atau mundurnya suatu bangsa, karena pendidikan merupakan proses untuk mengubah dan mengembangkan pengetahuan dan bukan sekadar mewarisi kebudayaan dari generasi ke generasi. Pendidikan adalah tanggungjawab bersama antara keluarga, sekolah, masyarakat, dan pemerintah, termasuk di sini adalah tanggungjawab untuk meningkatkan baca tulis al-Qur'ân generasi umat Islam. Sebagaimana intruksi Menteri Agama nomor 3 tahun 1990, tentang pelaksanaan upaya peningkatan kemampuan baca tulis huruf alQur'ân. ${ }^{1}$

Sudah menjadi pengetahuan bersama bahwa al-Qur'ân adalah perkatan (kalâm) Allâh Ta'âlâ yang diturunkan dengan lisân orang Arab yang tentunya tidak semua suku maupun bangsa dapat membacanya dengan baik dan benar sesuai dengan kaidah tartil tanpa adanya usaha untuk mengucapkan huruf-hurufnya dengan tepat dan benar, karena alQur'ân ini memiliki beberapa kelebihan yang tidak dimiliki oleh kitabkitab suci lainnya.

Dengan demikian merupakan kewajiban seorang muslim terhadap al-Qur'ân adalah membacanya dengan baik dan benar sesuai kaidah tajwid yang disebut dengan bacaan tartil. Lalu pertanyaannya apakah bacaan al-Qur'ân kaum muslimin Indonesia sudah mencapai standar bacaan tartil? Sebagaimana yang Allâh Ta'âlâ firmankan "Dan bacalah al-Qur'ân itu dengan tartil" (Q.S Al-Muzzamil: 4).

Kalau diamati secara seksama kondisi ummat Islam Indonesia saat ini belum mencapai pada tingkatan bacaan tartil, karena realita bacaan al-Qur'ân yang ada pada kaum muslimin saat ini pada umumnya sangat jauh dari yang diharapkan seperti yang difirmankan Allâh Ta'âlâ di atas. Hal ini banyak dijumpai kebanyakan dari kaum muslimin jatuh kedalam kesalahan-kesalahan yang dapat menghilangkan ruh dari pada bacaan al-Qur'ân itu sendiri, seperti beberapa kesalahan yang sering terjadi adalah: 1. Kesalahan pada makhraj, 2. Kesalahan pada nada vocal

1 Departemen Agama, Proyek Pengadaan Kitab Suci al-Qur'ân (Jakarta: Depertemen Agama Pusat 1990/1991).

Jurnal Pendidikan Agama Islam

Volume 02 Nomor 02 November 2013

Hal 268 - 286 
dan dengung, 3. Kesalahan pada huruf-huruf sukun dan qalqalah, 4. Kesalahan pada Mad (bacaan panjang).

Kesalahan-kesalahan itu terjadi karena adanya beberapa faktor yang sangat mendominasi, artinya faktor-faktor tersebut dapat disebut sebagai sebab terjadinya kesalahan pada bacaan al-Qur'ân. Diantara hal yang menyebabkan kurang mampunya umat Islam Indonesia dalam membaca al-Qur'ân adalah status pengembangan metodologi pengajaran membaca al-Qur'ân selama ini hingga tahun 1990-an, metode yang banyak di pakai adalah metode yang tertuang dalam "al-Qawâ'idul Baghdâdiyah" atau biasa dikenal dengan "tuntunan" atau "Juz 'Amma", dengan metode ini menyebabkan anak belajar harus memakan waktu 2-3 tahun untuk bisa membaca al-Qur'ân. Akibatnya banyak anak yang drop out sebelum ia mampu membaca al-Qur'ân, jadilah ia buta huruf alQur'ân selamanya. ${ }^{2}$

Pembelajaran al-Qur'an hendaklah dilakukan mulai sejak masa dini atau masa anak-anak karena masa kanak-kanak adalah masa awal perkembangan kepribadian manusia, apabila kita mengajarkan sesuatu yang baik maka akan memperoleh hasil yang baik. ${ }^{3}$ Begitu juga mengajarkan Al-Qur'an pada masa itu maka akan mudah diserap oleh mereka.

Dengan pembelajaran Al-Qur'an pada masa usia dini akan berfungsi untuk memberikan pengalaman belajar kepada anak, tetapi yang lebih penting berfungsi untuk mengoptimalkan perkembangan otak. Dalam pembelajaran ini dapat berlangsung kapan saja dan dimana saja seperti halnya interaksi manusia yang terjadi didalam keluarga, teman sebaya, dan dari hubungan kemasyarakatan yang sesuai dengan kondisi dan perkembangan anak dini usia. ${ }^{4}$ Imam Suyuti mengatakan bahwa mengajarkan Al-Qur'an pada anak-anak merupakan salah satu diantara pilar-pilar Islam, sehingga mereka bisa tumbuh di atas fitrah. Begitu juga

\footnotetext{
${ }^{2}$ Team Tadarus AMM, Prinsip-prinsip Metodologi Buku Iqra' (Yogyakarta: LPTQ Nasional), 2-3.

${ }^{3}$ Mahmud Al-Khalawi, Mendidik Anak dengan Cerdas, (Sukoharjo: Insan Kamil, 2007), 147

${ }^{4}$ Anwar dan Arsyad Ahmad, Pendidikan Anak Dini Usia, (Bandung; PT Afabeta, 2004), 2
} 
cahaya hikmah akan terlebih dahulu masuk ke dalam hati mereka, sebelum dikuasai oleh hawa nafsu dan dinodai oleh kemaksiatan. ${ }^{5}$

Tujuan membaca Al-Qur'an telah dijelaskan dalam buku Petunjuk Teknis dan Pedoman Pembinaan Baca Tulis al-Qur'an dinyatakan bahwa tujuan baca tulis Al-Qur'an adalah menyiapkan anak didiknya agar menjadi generasi muslim yang Qur'ani, yaitu generasi yang mencintai Al- Qur'an, menjadikan Al-Qur'an sebagai bacaan, dan sekaligus pandangan hidupnya sehari-hari. ${ }^{6}$ Seperti halnya dalam Surat Al-"Alaq ayat 1-5 yang berbunyi: Artinya: "Bacalah dengan (menyebut) nama Tuhanmu yang Menciptakan, Dia telah menciptakan manusia dari segumpal darah, Bacalah, dan Tuhanmulah yang Maha pemurah, Yang mengajar (manusia) dengan perantaran kalam (Maksudnya: Allah mengajar manusia dengan perantaraan tulis baca), Dia mengajar kepada manusia apa yang tidak diketahuinya.

Dalam mendidik anak yang paling bertanggung jawab adalah dari pihak keluarga. Seperti halnya pepatah mengatakan "Mendidik Anak Bagaikan Mengukir Diatas Batu". Meskipun mendidik anak begitu penuh tantangan, tetapi ketika seorang anak telah mampu memahami satu kata saja dari pendidiknya, ia akan tetap mengingatnya hingga dewasa kelak. ${ }^{7}$

Metode merupakan faktor yang paling penting dalam proses belajar mengajar, meskipun metode tidak akan berarti apa-apa, bila dipandang terpisah dari faktor- faktor yang lain dengan pengertian bahwa metode baru dianggap penting dalam hubungannya dengan semua faktor pendidikan lainnya, misalnya tujuan, materi, evaluasi dan lain sebagainya. Metode yang digunakan dalam pembelajaran Al-Qur'an sering kali tidak relevan walaupun sebenarnya dalam suatu lembaga itu sudah ada ketentuan dalam penggunaan metode pembelajaran Al-Qur'an tetapi kebanyakan dari pihak pendidik masih belum menerapkan atau menggunakan metode tersebut.

\footnotetext{
5 Muhammad Nur Abdul Hafidz Suwaid. Mendidik Anak Bersama Nabi, terjemahan Salafuddin Abu Sayyid, (Solo: Pustaka Arafah, 2003), 157-158

6 Muhaimin, Arah Baru Pengembangan Pendidikan Islam: Pemberdayaan, Pengembangan Kurikulum Hingga Redevisi Islamisasi Pengetahuan (Bandung: Nuansa, 2003), 121

${ }^{7}$ Muhaimin, Arah Baru Pengembangan Pendidikan Islam, 5. 
Berdasarkan hal itu seorang pendidik seharusnya dapat mengefektifkan metode pembelajaran yang telah ada menjadi sebuah metode baru yang dapat meningkatkan pembelajaran Al-Qur'an agar anak didik dapat belajar dengan cepat untuk mempelajari Al-Qur'an dan tidak terjadi kebosanan pada diri anak didik itu sendiri.

Penentuan metode pembelajaran Al-Qur'an ini dipandang sangat penting sekali sehingga peneliti memilih tempat penelitian di TPQ Sabilun Najah yang mana lembaga ini menggunakan metode Tartila. Adapun tujuan dari penggunaan metode Tartila ini diharapkan dapat mempermudah sekaligus mempercepat cara belajar baca Al-Qur'an anakanak. TPQ Sabilun Najah merupakan lembaga pendidikan Al-Qur'an yang berada di Sambiroto Taman Sidoarjo. TPQ ini bertempat di Masjid Sabilun Najah. TPQ Sabilun Najah merupakan salah satu TPQ yang menggunakan metode cepat belajar membaca Al-Qur'an yakni metode Tartila.

\section{B. Rumusan Masalah}

1. Bagaimanakah Pelaksanaan Pembelajaran al-Qur'an dengan Metode Tartila di TPQ Sabilun Najah?

2. Bagaimanakah Kualitas bacaan al-Qur'an Santri di TPQ Sabilun Najah?

\section{Metode Penelitian}

Penelitian ini merupakan field research (penelitian lapangan) yang mendeskripsikan data-data kulaitatif dan kuantitatif. Jenis data penelitian meliputi Data Primer, yaitu sumber yang langsung memberikan data kepada peneliti, ${ }^{8}$ diantaranya adalah: Kepala TPQ Sabilun Najah, Guru-guru yang mengajar Metode Tartila di TPQ Sabilun Najah, Peserta (Santri). Juga Data Sekunder, yaitu sumber data yang tidak langsung memberikan data kepada peneliti, ${ }^{9}$ seperti dokumentasi mengenai program pembelajaran, literatur-literatur mengenai metode tartila, dan lailain.

\footnotetext{
${ }^{8}$ Muhaimin, Arah Baru Pengembangan Pendidikan Islam, 308.

${ }^{9}$ Muhaimin, Arah Baru Pengembangan Pendidikan Islam, 309.
} 
Untuk mendapatkan data-data yang akurat, maka dalam penelitian ini digunakan beberapa metode, sebagai berikut: Observasi, Wawancara (interview), dan Dokumentasi. Data yang terkumpul dianalisis dengan tahapan: Reduksi Data, Penyajian Data, dan konklusi.

\section{Hasil Penelitian}

\section{Penerapan Metode Tartila di TPQ Sabilun Najah}

Tujuan pembelajaran dapat tercapai dengan baik, apabila pembelajaran dilaksanakan sebaik-baiknya dengan menggunakan model-model pembelajaran yang tepat. Dengan adanya model pembelajaran yang relevan, maka pelaksanaan pembelajaran akan berjalan lancar. Demikian pula dengan adanya metodologi dalam penyampaian pengetahuan akan menjadikan seseorang mudah dalam menerima materi yang telah disampaikan. Untuk menambah pengetahuan dan pengalaman yang lebih luas khususnya bagi guru yang mengajarkan Al-Qur'an dengan metode Tartila, maka semua dewan guru wajib mengikuti Penataran dan Pembinaan Guru AlQur'an yang diadakan oleh Jam'iyyatul Qurro' Wal Hufadz.

Kegiatan ini bertujuan untuk memperoleh syahadah sebagai syarat mengajarkan Al-Qur'an dengan menggunakan metode Tartila. Materi-materi yang diajarkan dalam kegiatan ini tentunya adalah materi-materi yang berhubungan dengan pengajaran dan pembelajaran Al-Qur'an melalui metode Tartila. Materi-materi tersebut diantaranya: materi Fiqih, management Tartila, cara mendirikan TPQ, visi dan misi Tartila, cara mengajarkan Al-Qur'an melalui metode Tartila, Ulumul Qur'an, cara membuka dan menutup kegiatan belajar mengajar, dan lain sebagainya.

Setelah para ustadzah mengikuti pembinaan dan memperoleh materi-materi yang berkaitan dengan pembelajaran Al-Qur'an dengan metode Tartila, selanjutnya para ustadzah diwajibkan mengikuti tashih. Setelah dinyatakan lulus tashih, mereka berhak mendapatkan syahadah sebagai syarat untuk mengajarkan Al-Qur'an khususnya dengan metode Tartila.

Pelaksanaan pembelajaran Al-Qur'an melalui metode Tartila di TPQ Sabilun Najah dilaksanakan secara rutin pada hari Senin 
sampai Sabtu, di mulai pada pukul 14.00 WIB sampai pukul 17.00 WIB. Yakni terdapat pembagian waktu, pukul 14.00-15.30 WIB ini untuk kelas dasar Jilid I dan Jilid II, dilanjutkan pukul 15.45-17.00 WIB ini untuk kelas dasar Jilid III-jilid VI dan juga Al-Qur'an. Sedangkan untuk hari Minggu dan hari-hari Besar Islam kegiatan pembelajaran Al-Qur'an libur. Sistem pembelajaran disini dibagi menjadi dua kelas, yaitu kelas Dasar dan kelas Al-Qur'an. Kelas Dasar merupakan kelas yang pertama kali harus ditempuh oleh santri sebelum memasuki kelas al-Qur'an dan yang termasuk didalamnya adalah santri kelas Tartila jilid 1-6 hingga pada kelas Al-Qur'an. Materi yang diberikan pada kelas dasar adalah berupa materi-materi tambahan, baik materi hafalan surat-surat pendek, hafalan do'a seharihari, praktek sholat, dan lain sebagainya. Sebagaimana yang disampaikan oleh Ustadzah Andriyani:

"Materi tambahan disampaikan kepada semua santri dalam sepekan disampaikan sekali, yakni dalam satu pekan kegiatan belajar mengajar diambil satu hari khusus untuk menyampaikan materi tambahan seperti do'a sehari-hari, hafalan surat pendek, praktik sholat, dan lain sebagainya." 10

Sedangkan kelas Al-Qur'an merupakan kelas berkelanjutan dari kelas dasar. Materi yang diberikan pada kelas al-Qur'an, pada dasarnya sama seperti kelas dasar bahkan hanya tinggal mengulang saja. Akan tetapi, hanya ada sedikit materi tambahan yang harus diperhatikan oleh santri. Materi tambahan tersebut adalah berupa materi yang berhubungan dengan materi Pendidikan Agama Islam (baik materi Fiqih, Aqidah Akhlaq, dan Sejarah Kebudayaan Islam (SKI)). Materi ini bertujuan untuk membekali santri yang pengetahuan agamanya masih kurang maksimal selama di peroleh saat berada di sekolah umum. Selain materi PAI, pada kelas al-Qur'an juga terdapat materi pokok seperti: materi yang berkaitan dengan Al-Qur'an, Ghorib dan Musykilat, Tajwid, dan hafalan juz 30.

${ }^{10}$ Hasil wawancara dengan ustadzah Andriyani, salah satu pengajar di TPQ sabilun Najah. Pada hari,Jum'at 20 April 2012. 
Adapun perincian kegiatan pembelajaran bagi kelas dasar dan kelas al-Qur'an adalah sebagai berikut: ${ }^{11}$

Kegiatan TPQ Sabilun Najah

\begin{tabular}{|c|l|}
\hline PUKUL & \multicolumn{1}{|c|}{ KEGIATAN } \\
\hline $15.45-$ & $\begin{array}{l}\text { Guru membariskan santri di dalam masjid } \\
\text { Sabilun Najah untuk membaca do'a bersama } \\
\text { dan asma'ul husna. }\end{array}$ \\
\hline 16.00 & Guru memulai kegiatan belajar-mengajar \\
$16.00-$ & sesuai jadwal dan tempatnya masing-masing. \\
\hline & $\begin{array}{l}\text { Guru bersiap-siap untuk mengakhiri kegiatan } \\
\text { belajar-mengajar, namun sebelum hal itu } \\
\text { dilakukan guru terlebih dahulu memberikan } \\
\text { materi yang terdapat di alat peraga sekitar 15 } \\
\text { menit. }\end{array}$ \\
\hline
\end{tabular}

Dengan adanya kelas dasar dan kelas al-Qur'an akan membantu santri untuk lebih memahami hukum-hukum bacaan yang ada di dalam Al-Qur'an dan senantiasa mengaplikasikannya dalam kehidupan sehari-hari. Pada dasarnya kedua kelas ini tidaklah menjadi persoalan yang dapat mengganggu proses kegiatan belajar-mengajar, meskipun pelaksanaannya ditetapkan dengan waktu yang sama. Akan tetapi, justru dengan adanya kelas dasar dan kelas al-Qur'an ini proses pembelajaran Al-Qur'an semakin lama semakin mengalami peningkatan, khususnya bagi keterampilan santri dalam membaca AlQur'an dengan tartil tentunya dengan bertajwid.

Penilaian buku Tartila dalam pengajaran dan pembelajaran Al-Qur'an berbeda dengan buku-buku yang menggunakan metode yang lain. Evaluasi atau penilaian yang terdapat pada buku Tartila hanya terdapat 2 lambang yaitu L (Lancar) dan TL (Tidak Lancar). Santri yang mendapat nilai $\mathrm{L}$ berarti santri tersebut boleh dan berhak melanjutkan ke halaman atau jilid berikutnya. Akan tetapi, jika nilai yang di dapat santri TL maka berarti santri masih tidak diperbolehkan untuk melanjutkan ke halaman berikutnya.

${ }^{11}$ Hasil wawancara dengan ustadzah Andriyani, salah satu pengajar di TPQ sabilun Najah. Pada hari,Jum'at 20 April 2012.

Jurnal Pendidikan Agama Islam

Volume 02 Nomor 02 November 2013

Hal $274-286$ 
Dalam pembelajaran Al-Qur'an dengan metode Tartila diperlukan sarana dan prasarana sebagai alat pendukung terlaksananya proses pembelajaran. Sarana dan prasarana yang tersedia di TPQ Sabilun Najah telah dijelaskan di point yang pertama di atas. Dengan adanya sarana dan prasarana yang memadai, maka proses pembelajaran akan mudah terlaksana dengan baik dan lancar. Oleh karena itu, tanpa adanya sarana dan prasarana yang mendukung bagi suatu lembaga maka pembelajaran tidak akan tercapai dengan baik sesuai dengan tujuan semula.

Diantara sarana dan prasarana tersebut diatas, yang paling urgen dan fundamental digunakan oleh pengajar terutama dalam mengajar Al-Qur'an dengan metode Tartila adalah adanya alat peraga dan buku jilid Tartila. Sebagaimana yang telah diungkapkan oleh ustadzah Dzikrotul bahwa:

"Alat peraga dan buku metode Tartila merupakan sarana yang paling urgen dalam mengajarkan Al-Qur'an melalui metode Tartila. Karena dengan adanya kedua sarana ini, santri akan lebih mudah mempelajari setiap jilid buku Tartila. Alat peraga ini berfungsi sebagai alat untuk mempermudah dan memperlancar bacaan santri secara klasikal. Sedangkan secara individual santri menggunakan buku Tartila. Dengan adanya buku Tartila bertujuan untuk mempermudah santri dalam membacanya setiap waktu baik sewaktu berada di kelas maupun di rumah." 12

Sebelum proses pembelajaran al-Qur'an melalui metode Tartila di TPQ Sabilun Najah berlangsung di kelas, hal-hal yang harus dilakukan oleh guru antara lain: ${ }^{13}$

a. Guru mengumpulkan seluruh santri di dalam masjid Sabilun Najah tepat pukul 15.45 WIB.

b. Guru memberi salam kepada seluruh santri.

${ }^{12}$ Hasil wawancara dengan ustadzah Dzikrotul Millah, salah satu pengajar di TPQ Sabilun Najah Sambiroto. Pada hari Senin, 21 April 2012.

${ }^{13}$ Observasi, tertanggal 21 April 2012. 
c. Guru memimpin do'a dan asma'ul husna, kemudian diikuti oleh seluruh santri bersama-sama.

d. Guru memberikan sedikit materi tambahan kepada santri selama 15 menit. Materi tambahan tersebut berupa hafalan surat-surat pendek dan do'a sehari-hari.

e. Guru memanggil santri sesuai dengan deretan kelas masing-masing untuk masuk ke kelas.

f. Bagi santri yang telat, guru memberikan peringatan kepada mereka, agar mereka tidak akan mengulangi perbuatannya lagi. Setelah memberikan peringatan, guru menyuruh santri untuk berdo'a dan menghafal do'a sehari-hari sebagaimana yang telah dilakukan sebelumnya.

Pelaksanaan pembelajaran Al-Qur'an melalui metode Tartila untuk masing-masing tingkatan jilid terdiri dari 3 tahap, diantaranya: ${ }^{14}$ a. Persiapan Pelaksanaan Pembelajaran di Kelas

Sebelum pelaksanaan proses pembelajaran dilakukan maka hal-hal yang perlu dipersiapkan oleh ustadzah maupun santri adalah sebagai berikut:

1) Ustadzah

a) Mempersiapkan alat peraga Tartila jilid 1-6.

b) Mengkondisikan santri.

c) Memberikan nasehat yang bersifat mendidik kepada santri sebelum proses pembelajaran dimulai.

d) Membacakan pokok bahasan yang terdapat pada alat peraga.

2) Santri

a) Menyiapkan alat-alat tulis.

b) Menyiapkan buku Tartila.

c) Menyiapkan buku penghubung dan meletakkannya di bangku guru.

d) Berdo'a.

Adanya persiapan dalam pelaksanaan pembelajaran sangatlah penting dilakukan. Sebagaimana yang telah diungkapkan oleh ustadzah Dzikrotul Millah, menyatakan bahwa:

${ }^{14}$ Observasi, tertanggal 21 April 2012.

Jurnal Pendidikan Agama Islam

Volume 02 Nomor 02 November 2013

Hal $276-286$ 
"Yang perlu dipersiapkan sebelum kegiatan belajar-mengajar adalah alat peraga dan media yang akan dipergunakan ketika proses pembelajaran berlangsung. Alat peraga dan media merupakan sarana yang sangat mendukung terlaksananya pengajaran Al-Qur'an dengan menggunakan metode Tartila. Akan tetapi, alat peraga digunakan hanya bagi Tartila jilid 1-6 saja,."15

Dari penjelasan yang peneliti peroleh selama observasi dan berdasarkan hasil interview, dapatlah ditarik kesimpulan bahwa sebelum proses pembelajaran di kelas berlangsung, diperlukan suatu persiapan yang matang dan terencana guna untuk mencapai tujuan yang telah ditetapkan. Tujuan yang dimaksud adalah untuk menciptakan santri yang mempunyai kemampuan baca Al-Qur'an dengan baik dan bertajwid.

b) Kegiatan Belajar-Mengajar (KBM)

Kegiatan belajar-mengajar dilakukan ketika persiapan pembelajaran sudah dilaksanakan dengan sebaik-baiknya. Kegiatan belajar-mengajar yang dilakukan di TPQ Sabilun Najah, adalah sebagai berikut:

1) Implementasi Proses Belajar-Mengajar

Pada dasarnya, penerapan metode Tartila untuk tiaptiap jilid berbeda. Karena masing-masing jilid mempunyai misi yang berbeda pula, sehingga dalam proses belajar santri harus disesuaikan dengan tingkatan jilid yang telah di capai oleh santri. Hal ini disebabkan hasil kemampuan baca yang dicapai oleh santri harus maksimal berdasarkan misi masing-masing jilid. Akan tetapi, dalam kemampuan baca yang dihasilkan dapat terlihat ketika terselesainya jilid itu sampai berapa lama. Dan untuk hasil kemampuan baca antara santri yang satu dengan santri yang lain berbeda. Dalam hal ini seperti yang telah diungkapkan oleh ustadzah Dzikro, bahwasannya:

"Hasil kemampuan baca santri dapat dilihat ketika terselesainya jilid itu sampai berapa lama. Biasanya ada

${ }^{15}$ Hasil wawancara dengan ustadzah Dzikrotul Millah, tertanggal 21 April 2012. 
santri yang mampu menyelesaikan jilidnya hanya 2 bulan saja baru bisa khotam, tetapi ada juga yang 6 bulan khotam, bahkan ada yang sampai setahun baru bisa menyelesaikan jilidnya. Bila santri rajin dan bersungguh-sungguh dalam belajar, maka dia akan khotam sesuai dengan target yang telah ditetapkan. Akan tetapi, jika santri bermalas-malasan bahkan sering tidak masuk, maka itu akan menghambat kelulusan santri. $^{16}$

Apabila santri mengalami kesulitan selama proses pembelajaran khususnya dalam membaca Al-Qur'an, maka tindakan yang harus dilakukan oleh seorang guru adalah mencari sebab-sebab mengapa hal itu bisa sampai terjadi. Selain itu, guru dapat memberikan training khusus yang bersifat kontinuitas kepada santri yang mengalami kesulitan tersebut. Hal ini juga telah diungkapkan oleh ustadz Rofiq, bahwa:

"Untuk mengatasi santri yang mengalami kesulitan dalam membaca Al-Qur'an itu tidak sulit dan juga tidak mudah. Hal ini dapat dilakukan melalui 3 macam cara. Pertama, guru hendaknya sering memantau (monitoring) keaktifan santri setiap hari selama proses pembelajaran. Kedua, guru hendaknya memberikan drill (latihan) kepada santri dengan baik. Dan ketiga, guru memanggil orang tua santri yang bersangkutan untuk melakukan tatap muka (pertemuan) antara guru dengan wali santri." $" 17$

Tujuan dari ketiga macam cara untuk mengatasi kesulitan santri dalam proses belajar adalah untuk memenuhi target yang ditetapkan oleh cabang. Dari target yang telah ditetapkan oleh cabang, ternyata lembaga TPQ Sabilun Najah

\footnotetext{
${ }^{16}$ Hasil wawancara dengan ustadzah Dzikrotul Millah, tertanggal 21 April 2012.

${ }^{17}$ Hasil wawancara dengan ustadz Ainur rofiq selaku kepala lembaga TPQ Sabilun Najah di Sambiroto, tepatnya pada tanggal 22 April 2012.

Jurnal Pendidikan Agama Islam

Volume 02 Nomor 02 November 2013

Hal $278-286$
} 
masih belum bisa meluluskan santri sesuai dengan target. Akan tetapi hal itu tidak berlangsung lama, karena dengan semangat dan motivasi yang tinggi dalam mendidik serta membimbing santri, para ustadzah TPQ Sabilun Najah tetap berusaha keras memberikan pengarahan kepada santri agar bisa membaca AlQur'an dengan tartil dan bertajwid.

Sesuai dengan penjelasan di atas, peneliti dapat memberikan kesimpulan bahwa dalam kegiatan belajarmengajar yang dilakukan oleh ustadzah dan santri di lembaga TPQ Sabilun Najahmasih dikatakan cukup baik. Hal ini disebabkan karena lembaga ini belum sepenuhnya dapat mengirimkan dalam arti mengikutkan santri untuk mengikuti ujian sesuai dengan target yang telah ditetapkan oleh Cabang.

Ini terjadi karena santri masih belum sanggup menyelesaikan jilidnya dengan baik atau masih banyak kesalahan yang diperbuat oleh santri dalam membaca AlQur'an. Akan tetapi hal ini dapat diatasi oleh pengajar dengan memberikan beberapa alternatif tindakan seperti: guru hendaknya selalu memonitoring keaktifan santri setiap kali proses belajar, guru hendaknya memberikan drill kepada santri, dan atau guru hendaknya mengajak orang tua santri yang bersangkutan untuk melakukan face to face bahkan jika perlu door to door antara pengajar dengan wali santri.

2) Implementasi Materi Tambahan

Untuk mencapai tujuan yang diharapkan, maka dibutuhan suatu materi sebagai sarana penunjang dalam kegiatan proses pembelajaran. Materi pembelajaran merupakan salah satu komponen dasar dalam kegiatan belajar membaca AlQur'an melalui metode Tartila yang harus disusun secara jelas dan tepat.

Adapun materi yang akan disampaikan oleh guru kepada santri kelas dasar ada 2 macam materi, yakni materi pokok dan materi tambahan. Materi pokok dan materi tambahan merupakan materi yang wajib dipelajari dan dihafalkan oleh santri. Karena kedua materi ini merupakan materi yang akan 
diujikan kepada santri, baik pada saat santri akan menghadapi tes pelajaran maupun saat tes khotam Al-Qur'an.

Sedangkan materi bagi santri yang kelas al-Qur'an, sebenarnya tidak jauh beda dengan kelas dasar. Hanya saja, santri yang sudah menempati kelas al-Qur'an memperoleh sedikit tambahan ilmu tentang Pendidikan Agama Islam (PAI), diantaranya: materi Fiqih, Akidah Akhlaq, Sejarah Kebudayaan Islam (SKI), dan lain sebagainya.

Berdasarkan penjelasan yang peneliti peroleh, bahwasannya dalam implementasi materi pokok maupun materi tambahan dalam pembelajaran Al- Qur'an khususnya melalui metode Tartila sudah berjalan sesuai dengan target masingmasing kelas dan berdasarkan pada tingkatan jilid santri.

c) Penilaian (Evaluasi)

Kegiatan belajar-mengajar dikatakan berhasil jika ada evaluasi dalam suatu lembaga. Tujuan diadakannya sebuah evaluasi pembelajaran adalah untuk mengetahui sejauh mana tingkat potensi santri dalam memahami materi yang telah disampaikan selama proses pengajaran dan pembelajaran berlangsung. Hasil evaluasi yang ada di dalam TPQ Sabilun Najah diklasifikasikan menjadi 3 tahap, yaitu: 1) evaluasi kenaikan jilid (Kepala TPQ). 2) evaluasi pada saat santri khotam Al-Qur'an (Jam'iyyatul Qrro' Wal Hufadz). Dan 3) evaluasi yang diberikan oleh wali santri ketika Imtihan berlangsung (Lembaga TPQ Sabilun Najah), sedangkan guru hanya berhak menaikkan halaman pada buku jilid Tartila saja.

Evaluasi pada saat kenaikan jilid memiliki perbedaan dan persamaan dengan evaluasi pada saat Tashih Akhir Santri. Secara prinsip, memang antara evaluasi kenaikan jilid dengan Santri Khotam Al-Qur'an muatannya sama. Namun dilihat dari segi teknisnya, model pengajarannya berbeda. Evaluasi pada saat kenaikan jilid dilaksanakan ketika santri mampu menyelesaikan dan menguasai jilid yang akan diujikan sesuai dengan jilid yang dipelajari. Sedangkan evaluasi pada saat Tashih Akhir Santri yaitu 
berupa materi secara universal baik materi pokok maupun materi tambahan.

Untuk mengetahui berhasil atau tidaknya santri itu tergantung pada guru yang memberikan pengajaran. Sebagaimana yang telah diungkapkan oleh ustadz Rofiq selaku Kepala TPQ Sabilun Najah sekaligus pengajar, mengungkapkan bahwa:

"Untuk mengukur tingkat keberhasilan santri, maka kami akan mengadakan tes kenaikan jilid yang harus dilalui oleh seluruh santri sebelum melanjutkan ke jilid berikutnya. Dan dari sinilah kami bisa melihat proses pembelajaran yang dilakukan oleh ustadzah-ustadzah itu dikatakan berhasil atau tidak dalam mengajarkan Al-Qur'an kepada santri. Jika santri dikatakan berhasil dalam menempuh tes kenaikan jilid sampai ke tingkat Al-Qur'an, maka santri harus mengikuti prosedur akhir yaitu mengikuti tes khotam Al-Qur'an sesuai dengan syarat-syarat yang telah ditentukan sebelumnya. Syarat-syarat tersebut diantaranya: tartil dalam membaca Al- Qur'an, fashohah yakni fasih dalam melafalkan bacaan Al-Qur'an, menguasai ilmu tajwid dan Ghoribul Musykilat, santri mampu mewaqafkan dan mengibtida'kan bacaan Al-Qur'an yang terlalu panjang, dan tahsin yakni santri bisa memperbaiki bacaanbacaan Al-Qur'an sesuai dengan kaidah-kaidah yang telah ditentukan." 18

Berdasarkan pada paparan di atas, maka peneliti dapat memberikan kesimpulan bahwa evaluasi atau penilaian dalam proses pembelajaran Al-Qur'an melalui metode Tartila di TPQ Sabilun Najah berjalan dengan baik. Hal ini dikarenakan adanya evaluasi melalui tes kelompok sebelum melakukan tes kenaikan jilid. Dengan demikian, kepala TPQ Sabilun Najah bisa melihat bagaimana proses pembelajaran Al-Qur'an yang dilakukan oleh setiap ustadzah, guna menentukan tingkat keberhasilan santri

${ }^{18}$ Hasil wawancara dengan ustadz Ainur rofiq selaku kepala lembaga TPQ Sabilun Najah di Sambiroto, tepatnya pada tanggal 22 April 2012. 
dalam mengajarkan Al-Qur'an secara tartil dan bertajwid kepada santri.

\section{Kualitas Bacaan Santri TPQ Sabilun Najah}

Kualitas bacaan al-Qur'an yang baik dan benar adalah benar bacaannya, baik dan lancar dalam melafadzkannya, tepat dan sesuai dari segi makhraj dan ilmu tajwidnya. ${ }^{19}$ Sesuai dengan paparan wawancara mengenai penerapan pembelajran Al-Qur'an di TPQ Sabilun Najah, maka peneliti dapat menyimpulkan bahwa kualitas bacaan Al-Qur'an santri mapun gurunya adalah baik. Dimana para guru sebelum diperkenankan untuk mengajar Al-Qur'an metode Tartila, terlebih dulu para calon pengajar ini harus mengikuti penataran yang diadakan oleh Jam'iyyatul Qurr' wal Huffadz Jawa Timur.

Sedangkan untuk para santrinya, untuk mendapatkan bacaan Al-Qur'an yang berkualitas para santri harus mengikuti tiga tahapan tes atau evaluasi, yakni dari tahap tes kenaikan halaman yang setiap harinya dipantau oleh guru kelasnya masing-masing. Setelah dinyatakan lancar dan santri mampu mengikuti tes kenaikan jilid, maka santri akan dites langsung oleh kepala TPQ, dan tahap akhir adalah ketika santri akan mengikuti imtihan yakni evaluasi ditingkat wilayah yang secara langsung dites oleh Jam'iyyatul qurro' wal Huffadz, pihak TPQ Sabilun Najah mendatangkan para penguji dari JamQur (Jam'iyyatul Qurro' wal Huffadz) ke TPQ Sabilun Najah untuk mengadakan Tes Akhir Santri. Setelah santri dinyatakan lulus maka santri berhak mengikuti acara wisuda atau imtihan yang secara langsung akan dievaluasi kembali oleh para wali masing-masing santri.

\section{E. Analisis Data}

Kualitas bacaan al-Qur'an yang baik dan benar adalah benar bacaannya, baik dan lancar dalam melafadzkannya, tepat dan sesuai dari

\footnotetext{
19 Pusat Lektur Keagamaan Badan Litbang dan Diklat Depag R.I, Kemampuan Baca Tulis Al-Qur'an Siswa SMA (Jakarta: Balitbang Diklat Depag RI, 2007), 1.

Jurnal Pendidikan Agama Islam

Volume 02 Nomor 02 November 2013

Hal $282-286$
} 
segi makhraj dan ilmu tajwidnya. ${ }^{20}$ Sedangkan ilmu tajwid itu sendiri bertujuan agar umat Islam bisa membaca al-Qur'an sesuai dengan bacaan yang diajarkan Rasulullah Saw dan para sahabat-sahabatnya sebagaimana al-Qur'an diturunkan. ${ }^{21}$

Pembelajaran Al-Qur'an adalah suatu proses belajar Al-Qur'an yang disampaikan oleh pendidik kepada peserta didik, dengan tujuan agar peserta didik dapat membaca Al-Qur'an dengan tartil, baik dan benar sesuai kaidah-kaidah yang telah ditentukan. Pembelajaran Al-Qur'an metode Tartila merupaka sebuah cara pembelajaran al-Qur'an dengan pendekatan fungsi huruf atau pendekatan bunyi (at-thariqah alshauthyyah), yaitu pembelajaran membaca huruf arab langsung bersyakal. Serta menggunakan metode penyusunan (al-tariqah altarkibiyyah), yaitu dimulai dari pembelajaran membaca huruf menuju kata, kalimat sampai pembelajaran membaca ayat.

Dari hasil temuan data di lapangan, maka terdapat korelasi antara pembelajaran Al-Qur'an metode Tartila dalam meningkatkan kualitas bacaan Al-Qur'an Santri TPQ Sabilun Najah Sambiroto Taman-Sidoarjo. Hal ini dapat terlihat dari jawaban santri atas angket yang telah disebar oleh peneliti. Ada beberapa indikator bahwa Pembeljaran Al-Qur'an Metode Tartila evektif dalam meningkatkan kualitas bacaan Al-Qur'an Santri TPQ Sabilun Najah Sambiroto Taman-Sidoarjo. Adapun indikator tersebut adalah:

1. Santri Mampu Membaca Al-Qur'an dengan Lancar

Dari hasil yang ada santri mampu membaca Al-Qur'an dengan Lancar, hal ini terbukti dengan hasil prosentase 82,2 \% santri menjawab "ya" mengenai pertanyaan apakah santri lebih mudah dan lancar ketika membaca Al-Qur'an. Dikatakan lancar ketika santri membaca Al-Qur'an dalam satu ayat tidak terdapat kesalahan dan santri dengan tanpa berhenti (terputus-putus) ketika dalam membaca satu ayat Al-Qur'an tersebut.

20 Pusat Lektur Keagamaan Badan Litbang dan Diklat Depag R.I, Kemampuan Baca Tulis Al-Qur'an Siswa SMA, 1.

21 Ahmad Shams Madyan, Peta Pembelajaran Al-Qur'an, (Yogyakarta: Pustaka Belajar, 2008), 107. 
2. Siswa Lebih Berhati-hati dalam Membaca Al-Qur'an

Selain santri telah lancar membaca Al-Qur'an seperti yang dijelaskan sebelumnya, dalam hal ini santri juga lebih berhati-hati dalam melafadzkan huruf-huruf Al-Qur'an sesuai dengan sifatnya (Shifatul Huruf) dan juga sesuai dengan Makhrajnya, jadi santri tidak sembarang lancar membaca Al-Qur'an dan cepat saja, akan tetapi lebih berhati-hati dan dengan benar melafadzkan huruf-huruf AlQur'an sesuai dengan sifat dan makhrajnya. Jumlah prosentase santri yang menjawab "ya" adalah $88,9 \%$ dari pertanyaan santri merasa lebih hati-hati ketika melafadzkan huruf-huruf dalam Al-Qur'an.

3. Siswa Mampu Membaca Al-Qur'an dengan Benar (Sesuai dengan Kaidah Tajwid)

Dari hasil yang ada siswa mampu menerapkan kaidah tajwid dalam bacaan Al-Qur'an, sehingga santri telah bisa membaca AlQur'an dengan benar dan tartil, hal ini terbukti dengan hasil prosentase adalah $73,3 \%$ siswa menjawab "ya" mengenai pertanyaan mampu menerapkan ilmu tajwid dalam bacaan Al-Qur'an. Dalam penerapannya santri satu dengan yang lain saling menyimak dan guru memberikan kesempatan kepada santri untuk mengurai pelajaran tajwid dalam satu ayat yang telah dibaca secara bergantian. Jika ada yang salah penyebutan pelajaran tajwid yang ada ataupun terlewat, maka teman yang lainlah yang membenarkan. Karenanya secara otomatis para santri bisa membaca Al-Qur'an dengan benar dan sesuai dengan kaidah tajwid.

4. Siswa Mampu Merasakan dan Berhenti Membaca ketika Salah dalam Bacaan Al-Qur'an yang tidak Sesuai dengan Ilmu tajwid

Hal ini terlihat ketika santri satu membaca Al-Qur'an secara bergantian dengan disimak ustadzah dan teman-temannya, ketika ia mengucapkan kalimat yang salah membaca Al-Qur'an maka dengan sendirinya santri tersebut berhenti dan mengulangi membaca dari awal. Hal ini dimulai dari pembiasaan oleh ustadz/dzahnya mengajarkan kepada santri untuk serius menyimak dan secara langsung mengingatkan teman yang membaca jika ada kesalahan dalam bacaannya. Pernyataan ini peniliti ambil ketika melakukan wawancara terhadap ustadzah pengajar kelas tingkat al-Qur'an akhir, 
serta angket yang disebarkan kepada siswa dengan Prosentase 75,6 \% memberi jawaban "ya", ketika menjawab pertanyaan mengenai kemampuan menyimak santri jika terdapat kesalahan membaca AlQur'an.

Dari beberapa indikator di atas, maka diambil kesimpulan bahwasanya pembelajaran Al-Qur'an dengan menggunakan metode Tartila efektif dalam meningkatkan kualitas bacaan Al-Qur'an santri TPQ Sabilun Najah Sambiroto, Taman-Sidoarjo.

\section{F. Kesimpulan}

TPQ Sabilun Najah telah menerapkan metode Tartila dalam pembelajaran Al-Qur'an. Langkah-langkah yang dilakukan adalah sebagai berikut: 1. Persiapan Pelaksanaan Pembelajaran di Kelas, 2. Kegiatan Belajar Mengajar (KBM), 3. Penilaian (Evaluasi).

Kualitas bacaan Al-Qur'an santri maupun gurunya cukup baik. Dimana para guru sebelum diperkenankan untuk mengajar Al-Qur'an metode Tartila, terlebih dulu para calon pengajar ini harus mengikuti penataran yang diadakan oleh Jam'iyyatul Qurr' wal Huffadz (Jamqur) Jawa Timur. Sedangkan untuk para santrinya, untuk mendapatkan bacaan Al-Qur'an yang berkualitas para santri harus mengikuti tiga tahapan tes atau evaluasi, yakni dari tahap tes kenaikan halaman yang setiap harinya dipantau oleh guru kelasnya masing-masing. Setelah dinyatakan lancar dan santri mampu mengikuti tes kenaikan jilid, maka santri akan dites langsung oleh kepala TPQ, dan tahap akhir adalah ketika santri akan mengikuti imtihan yakni evaluasi ditingkat wilayah yang secara langsung dites oleh Jam'iyyatul qurro' wal Huffadz, pihak TPQ Sabilun Najah mendatangkan para penguji dari Jamqur ke TPQ Sabilun Najah untuk mengadakan Tes Akhir Santri.

Pembelajaran Al-Qur'an dengan menggunakan metode Tartila sangat efektif dalam meningkatkan kualitas bacaan Al-Qur'an santri di TPQ Sabilun Najah, dengan indikator santri mampu membaca Al-Qur'an dengan lancar, santri lebih berhati-hati dalam melafadzkan bacaan AlQur'an, santri mampu membaca Al-Qur'an dengan benar, dan santri mampu merasakan dan berhenti membaca ketika salah dalam membaca Al-Qur'an. 


\section{DAFTAR PUSTAKA}

Ahmad Shams Madyan, Peta Pembelajaran Al-Qur'an, (Yogyakarta: Pustaka Belajar, 2008).

Anwar dan Arsyad Ahmad, Pendidikan Anak Dini Usia, (Bandung; PT Afabeta, 2004).

Departemen Agama, Proyek Pengadaan Kitab Suci al-Qur'ân (Jakarta: Depertemen Agama Pusat, 1990/1991).

Mahmud Al-Khalawi, Mendidik Anak dengan Cerdas, (Sukoharjo: Insan Kamil, 2007).

Muhammad Nur Abdul Hafidz Suwaid, Mendidik Anak Bersama Nabi, terjemahan Salafuddin Abu Sayyid, (Solo: Pustaka Arafah, 2003).

Muhaimin, Arah Baru Pengembangan Pendidikan Islam: Pemberdayaan, Pengembangan Kurikulum Hingga Redevisi Islamisasi Pengetahuan (Bandung: Nuansa, 2003).

Pusat Lektur Keagamaan Badan Litbang dan Diklat Depag R.I, Kemampuan Baca Tulis Al-Qur'an Siswa SMA (Jakarta: Balitbang Diklat Depag RI, 2007).

Team Tadarus AMM, Prinsip-prinsip Metodologi Buku Iqra' (Yogyakarta: LPTQ Nasional).

\section{Sumber Lapangan:}

Hasil wawancara dengan ustadzah Andriyani, salah satu pengajar di TPQ sabilun Najah. Pada hari,Jum'at 20 April 2012.

Hasil wawancara dengan ustadzah Dzikrotul Millah, salah satu pengajar di TPQ Sabilun Najah Sambiroto. Pada hari Senin, 21 April 2012.

Hasil wawancara dengan ustadz Ainur rofiq selaku kepala lembaga TPQ Sabilun Najah di Sambiroto, tepatnya pada tanggal 22 April 2012.

Observasi, tertanggal 21 April 2012. 